\title{
ENFLURANE (ETTHRANE*) AND ISOFLURANE (FORANE*): A COMPARISON WITH NINE GENERAL ANAESTHETICS ADMINISTERED WITH PASSIVE HYPERVENTILATION
}

\author{
Allen B. Dobrin, Peter H. Byles, Benjamin F. Africa, \\ AND ASHLEY A. LeVY
}

\begin{abstract}
DURING THE INITIAL DEVELOPMENT of enflurane, it was observed that neuromuscular disturbances occurred. ${ }^{1}$ This was attributed by us to an excessive depth of anaesthesia. ${ }^{2,3}$ Later reports imputed hyperventilation and hypocarbia as the reason. ${ }^{4}$ Extensive and careful examination of the subject, supported by analysis of electroencephalograms, indicated indeed that this was a possibility, but all inhalation anaesthetics cause EEG changes, some of which show patterns similar to those accompanied by neuromuscular twitching. ${ }^{\overline{5}}$ The clinical manifestation of the EEG effect does not appear with enflurane unless an excessive depth of anaesthesia is used. With isoflurane, clinical manifestations have not been reported and the EEG appearance indicates the possibility is less likely. Therefore, this study was directed primarily to determining whether passive hyperventilation caused appreciable cardiovascular or metabolic disturbances and delayed recovery with enflurane and isoflurane and, only incidentally, if clinical neuromuscular disturbances would appear at a depth of anaesthesia that provided surgical anaesthesia and muscular relaxation. Similar anaesthetic conditions were produced with nine other agents for comparison purposes. None of these ordinarily cause neuromuscular disturbances.
\end{abstract}

\section{METHODS}

Anaesthesia was administered to 22 large, healthy, male, mongrel dogs ( 17 to $32 \mathrm{~kg}$ ) at approximately two-week intervals, employing the 11 agents shown in Table I for maintenance. Each agent was used at least ten times and each animal was anaesthetized with five or six different agents in a crossover design. A high protein diet was provided for one month prior to testing and during the intervals between tests. In each of the 115 experiments, an unpremedicated dog, fasted overnight, was first weighed; a 16-gauge plastic cannula was inserted in a foreleg vein and $20 \mathrm{mg} / \mathrm{kg}$ of thiopentone ( 2 per cent) was administered slowly. The cannula was attached to a regulated infusion of 0.9 per cent saline. A cuffed tracheal tube was inserted without using a muscle relaxant and attached to an anaesthetic machine delivering 50 per cent $\mathrm{N}_{2} \mathrm{O}$ and 50 per cent $\mathrm{O}_{2}$ with a Fink non-rebreathing valve. The animal was allowed to breathe spontaneously. A femoral artery was cannulated percutaneously and attached to a Statham strain

From the Department of Anesthesiology, State University of New York, Upstate Medical Center, Syracuse, New York, 13210, U.S.A.

"Trademark of Ohio Medical Products, Division of AIRCO Inc. 
TABLE I

Anaesthetic Agents and Vapourisers Used for 90 Minutes Following Induction WITH THIOPENTONE (20 mg/kg l.V.) HyPERVENTILATION: $\mathrm{TV}=1.5 \mathrm{mg} / \mathrm{kg} \sim 25 / \mathrm{MIN}$ )



*Attained in 30 minutes and maintained $\sim 60$ minutes.

†Vapourisers calibrated and checked with gas chromatograpl..

gauge and to a Grass polygraph through a 3-way stopcock to allow for blood sampling. ECG (lead II) was applied and recorded on the polygraph. A rectal telethermometer probe (Yellow Springs Instruments Co., Inc.) and a urinary catheter, attached to a calibrated trap, were also inserted. Following these preparations, venous and arterial blood samples were drawn for laboratory tests (control). A respirator was then attached in place of the reservoir bag on the gas machine (Table I). At this time the maintenance agent was begun. With the nine inhalation agents, the inhaled concentration was gradually increased to the maximum selected over the first 30 minutes and then maintained at this level for the remaining 60 minutes of the test. With the parenteral anaesthetics (thiopentone and Innovar) the infusion dose was given over the first hour and then saline only was administered for the remaining 30 minutes. Passive hyperventilation was provided by setting the ventilator at a tidal volume of $15 \mathrm{ml} / \mathrm{kg}$ body weight of the dog at a rate of approximately 25 per minute. All experiments were done in the morning during the summer months (June to August). The ambient temperature of the laboratory was kept warm $\left(23^{\circ} \mathrm{C}\right.$ to $\left.25^{\circ} \mathrm{C}\right)$.

At the end of the test period, venous and arterial blood samples were drawn again and total urine output and saline infusion volumes were recorded. All anaesthetics were then turned oft and pulmonary ventilation was assisted manually with 100 per cent oxygen until spontaneous respiration returned. Cannulas and recording instruments were then removed. When breathing was judged adequate, the tracheal tube was removed. The animal was then observed closely until it was awake, ambulant, and had a steady gait. Notes were kept of the rate of recovery and of clinical events such as shivering, gastrointestinal disturbances and ataxia.

\section{Laboratory Procedures}

An Instrumentation Laboratories, Inc., Model 113, pH/blood-gas analyzer was used to determine $\mathrm{pH}, \mathrm{Pa}_{\mathrm{co}_{2}}$ and $\mathrm{Pa}_{\mathrm{O}_{2}}$, in anaerobically drawn, heparinized arterial 
TABLE II

Sumpary of Changes in Mean Arterial Blood Prissure (Tork), Heart Rate (PER Minute), U'RINe OUTPUT (ml) and 0.9 per CENT Saline (ml) Administered During Aditsistration of General Axaesthesia WITH HYPERVENTILATION

\begin{tabular}{|c|c|c|c|c|c|}
\hline Minutes & 0 & 30 & 60 & 90 & $\frac{\text { Saline in }}{\text { urine out }}$ \\
\hline Methoxyflurane & $\begin{array}{l}* 135 \\
+163\end{array}$ & $\begin{array}{l}129 \\
113\end{array}$ & $\begin{array}{l}127 \\
122\end{array}$ & $\begin{array}{l}117 \\
133\end{array}$ & $\begin{array}{r}161 \\
99\end{array}$ \\
\hline Chloroform & $\begin{array}{l}137 \\
1.5\end{array}$ & $\begin{array}{l}140 \\
109\end{array}$ & $\begin{array}{l}145 \\
123\end{array}$ & $\begin{array}{l}13 i \\
130\end{array}$ & $\begin{array}{l}195 \\
102\end{array}$ \\
\hline Trichlorethylene & $\begin{array}{l}119 \\
124\end{array}$ & $\begin{array}{l}128 \\
105\end{array}$ & $\begin{array}{l}133 \\
122\end{array}$ & $\begin{array}{l}118 \\
129\end{array}$ & $\begin{array}{r}200 \\
76\end{array}$ \\
\hline Halothane & $\begin{array}{l}117 \\
119\end{array}$ & $\begin{array}{l}100 \\
104\end{array}$ & $\begin{array}{l}110 \\
12 \pi\end{array}$ & $\begin{array}{l}105 \\
127\end{array}$ & $\begin{array}{l}172 \\
111\end{array}$ \\
\hline HE Azeotrope & $\begin{array}{l}137 \\
133\end{array}$ & $\begin{array}{r}118 \\
96\end{array}$ & $\begin{array}{l}117 \\
10:\end{array}$ & $\begin{array}{r}99 \\
108\end{array}$ & $\begin{array}{r}180 \\
71\end{array}$ \\
\hline Isoflurane & $\begin{array}{l}132 \\
145\end{array}$ & $\begin{array}{r}74 \\
110\end{array}$ & $\begin{array}{r}88 \\
110\end{array}$ & $\begin{array}{r}67 \\
111\end{array}$ & $\begin{array}{r}173 \\
71\end{array}$ \\
\hline Enflurane & $\begin{array}{l}137 \\
147\end{array}$ & $\begin{array}{r}100 \\
81\end{array}$ & $\begin{array}{r}111 \\
88\end{array}$ & $\begin{array}{l}99 \\
94\end{array}$ & $\begin{array}{r}164 \\
87\end{array}$ \\
\hline Diethyl Ether & $\begin{array}{l}134 \\
154\end{array}$ & $\begin{array}{l}139 \\
144\end{array}$ & $\begin{array}{l}140 \\
175\end{array}$ & $\begin{array}{l}13 \pi \\
164\end{array}$ & $\begin{array}{r}2: 30 \\
95\end{array}$ \\
\hline Fluroxene & $\begin{array}{l}137 \\
133\end{array}$ & $\begin{array}{l}146 \\
106\end{array}$ & $\begin{array}{l}143 \\
127\end{array}$ & $\begin{array}{l}139 \\
144\end{array}$ & $\begin{array}{r}200 \\
76\end{array}$ \\
\hline Innovar & $\begin{array}{l}128 \\
120\end{array}$ & $\begin{array}{r}103 \\
91\end{array}$ & $\begin{array}{r}113 \\
89\end{array}$ & $\begin{array}{r}104 \\
81\end{array}$ & $\begin{array}{l}247 \\
135\end{array}$ \\
\hline Thiopentone & $\begin{array}{l}139 \\
148\end{array}$ & $\begin{array}{l}130 \\
138\end{array}$ & $\begin{array}{l}142 \\
148\end{array}$ & $\begin{array}{l}1: 1 \\
170\end{array}$ & $\begin{array}{l}248 \\
206\end{array}$ \\
\hline
\end{tabular}

* Mean arterial blood pressure (torr)

tHeart rate per minute.

blood. The same samples were used to determine oxygen saturation with a reflection oximeter made by American Optical Company (Model 10,800) and haematocrit was measured by a micromethod. Free-flowing arterial blood was collected to determine lactate and pyruvate by the method of Neville and Gelder. ${ }^{6}$ Blood sugar, serum inorganic phosphorus, bilirubin, calcium, potassium, sodium, blood urea nitrogen, creatinine, transaminases and urinalysis were done by standard laboratory procedures. Biogenic amines were measured by methods described previously, using the Aminco-Bowman Spectrophotofluorometer with a fluoromicrophotometer. ${ }^{7.8}$ Blood insulin levels were determined by an immunoassay method:"

\section{Results}

The control values of all the tests were influenced to some extent by the initial administration of thiopentone $20 \mathrm{mg} / \mathrm{kg}$ and 50 per cent nitrous oxide, but these effects were present in all the experiments and were undoubtedly small since the preparations usually consumed about 20 minutes, by which time any residual cardiovascular effects had probably disappeared. The hypoxaemia apparent in the "control" blood sample was corrected during passive hyperventilation. 


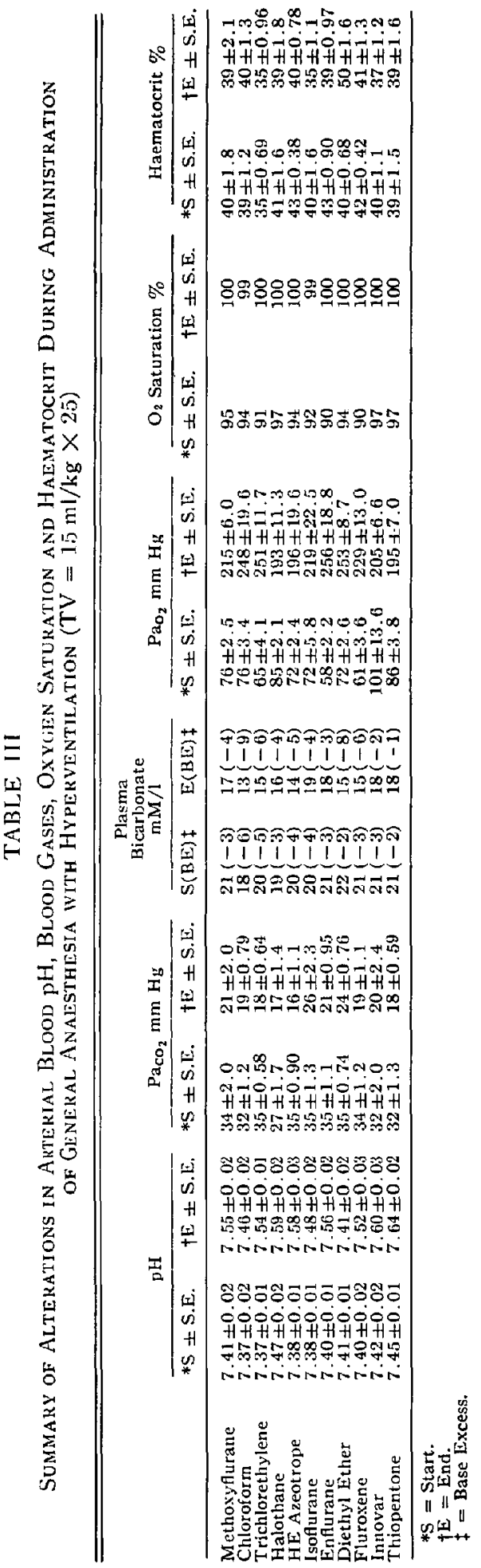


TABLE IV

Summary of Alterations in Blood Sugar, Serum Potassivi and Serlin Inorganic Phosphorus Duking Administration of General Anaesthesia with HyPERVENTILATION $(1 ; \mathrm{ml} / \mathrm{kg} \times 2 i)$

\begin{tabular}{|c|c|c|c|c|c|c|}
\hline & \multicolumn{2}{|c|}{$\begin{array}{c}\text { Blood Sugar } \\
\text { (ing } \%)\end{array}$} & \multicolumn{2}{|c|}{$\begin{array}{l}\text { Potassium } \\
(\mathrm{mEq} / \%)\end{array}$} & \multicolumn{2}{|c|}{$\begin{array}{c}\text { Inorganic Phosphorus } \\
(\mathrm{mg} \%)\end{array}$} \\
\hline & Start S.E. & End S.E. & itart S.E. & End S.E. & Start S.E. & End S.E. \\
\hline Methoxyflurane & $88 \pm 2.6$ & $97 \pm \bar{i}$. & \pm 0 & 4.7 & $4 . j \pm 0.22$ & $4.3=$ \\
\hline $\mathrm{c}$ & $122 \pm 12.0$ & $132 \pm 9$ & $=0.09$ & . & 0.27 & .29 \\
\hline Trichlorethylene & $116 \pm 4.6$ & $149 \pm 7.1$ & $=0.10$ & 0.09 & $=0.11$ & $\pm 0.1 j$ \\
\hline & $90 \pm 2.8$ & $101 \pm 3.9$ & $5.6 \pm 0.11$ & $4.4 \pm 0.14$ & $4.6 \pm 0.18$ & $3.5 \pm 0.28$ \\
\hline$e$ & $104 \pm 4.5$ & $113 \pm 4.6$ & $4.4 \pm 0.09$ & $=0.08$ & $4.1 \pm 0.21$ & $4.3 \pm 0$ \\
\hline & $89 \pm 2.2$ & $103 \pm 2.8$ & $4.1 \pm 0.07$ & $3.6 \pm 0$ & $4.3 \pm 0.32$ & $5.3 \pm 0.21$ \\
\hline Enf & $86 \pm 1.9$ & $93 \pm 3.7$ & $4.0 \pm 0.15$ & $3.6 \pm 0.13$ & $3.9 \pm 0.21$ & $4.4 \pm 0.26$ \\
\hline yl Ether & $104 \pm 8.3$ & $149 \pm 15.6$ & $3.8 \pm 0.10$ & $2.6 \pm 0.12$ & $3.8 \pm 0.17$ & $4.2 \pm 0.26$ \\
\hline Fluroxene & $109 \pm 3.6$ & $136 \pm 6.3$ & $4.4 \pm 0.10$ & $3.4 \pm 0.14$ & $4.2 \pm 0.26$ & $3.7 \pm 0.28$ \\
\hline & $86 \pm 1.6$ & $101 \pm 8.5$ & $56 \pm 0.08$ & $4.3 \pm 0.21$ & $4.3 \pm 0.17$ & $3.3 \pm 0.33$ \\
\hline Thiopentone & $90 \pm 1.3$ & $97 \pm 3.0$ & \pm 0.11 & $4.6 \pm 0.16$ & $4.5 \pm 0.20$ & $3.3 \pm 0.32$ \\
\hline
\end{tabular}

Arterial Blood Pressure (torr), Pulse Rate/min, Electrocardiogram (ECG) and Urine Output ( $\mathrm{ml}$ ) - (Table II)

Except with chloroform, trichlorethylene, diethyl ether, fluroxene and thiopentone, there was a progressive reduction in the arterial blood pressure. This effect was marked with isoflurane, probably due mainly to deep anaesthesia. The pulse rate decreased initially with all agents, but tended to recover or stabilize except with Innovar. No persistent arrhythmins occurred in lead 2 of the ECG. Premature ventricular contractions, nodal rhythms, or serious conduction abnormalities were virtually absent with all the agents. Urine output exceeded $60 \mathrm{ml}$. in every experiment indicating that, although passive hyperventilation is expected to ensure a high blood level of the anaesthetics, an antidiuretic effect was not evident and, with the two parenteral anaesthetics (Innovar and thiopentone), urine output was relatively high. Body temperature was reduced slightly $\left(<1.5^{\circ} \mathrm{C}\right)$ in most of the experiments. None of the animals developed neuromuscular twitching during or following the anaesthetics.

\section{Blood Gases, pH, Plasma Bicarbonate and Haematocrit (Table III)}

The control values showed a mild metabolic acidosis, probably due to fasting and a respiratory alkalosis induced by the combination of very light anesthesia and the stimulation of the tracheal tube and arterial cannulation. During the experiments, respiratory alkalosis developed in every case, but significant changes in the metabolic component were only seen with diethyl ether, where the base deficit increased by $6 \mathrm{mEq} / \mathrm{l}$. As expected, oxygen tension and percent saturation rose in all tests. The haematocrit remained essentially the same except with diethyl ether, which caused haemoconcentration.

\section{Blood Chemistry (Tables IV and V)}

No appreciable alteration occurred in the serum sodium, calcium, bilirubin, urea nitrogen, creatinine or transaminases. Serum potassium was reduced 15 to 20 


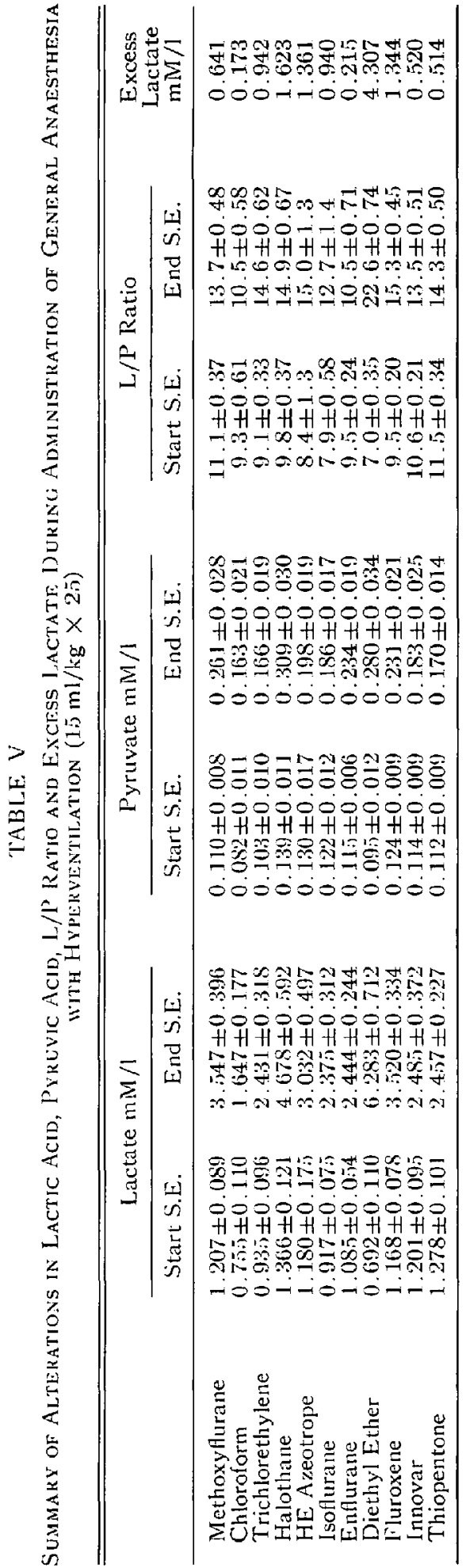




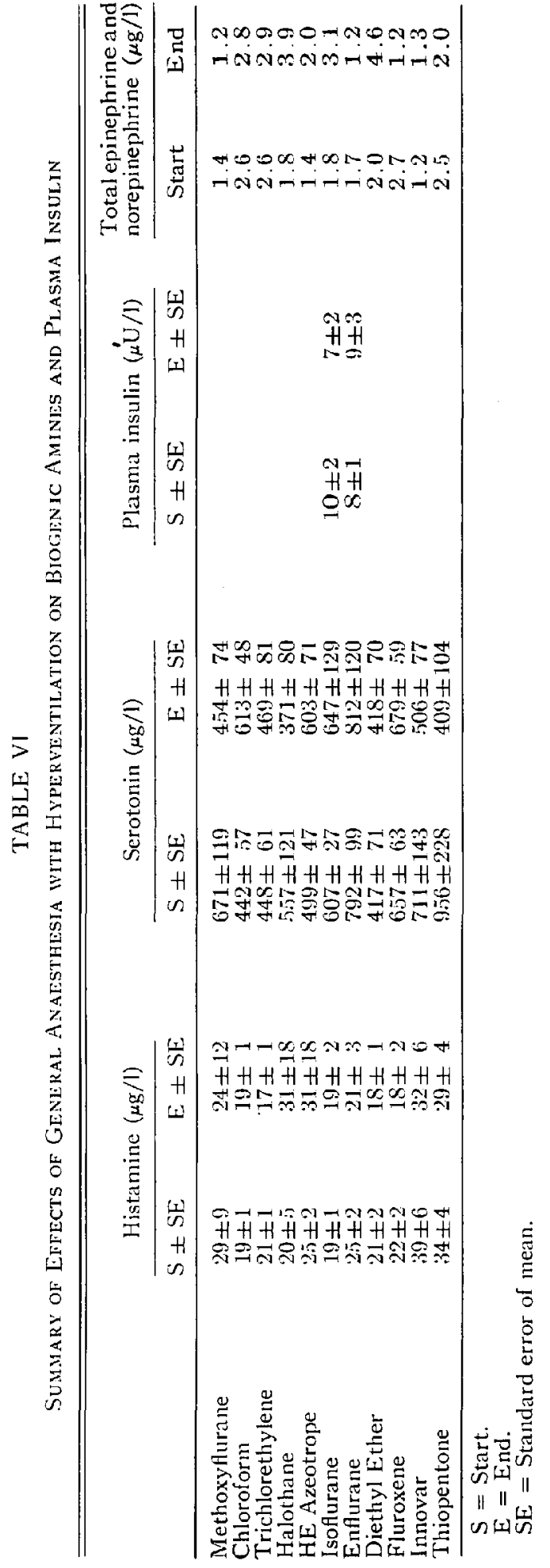


TABLE VII

Recovery of Spontaneous Respiration (SR) and Steady Ambulation (SA) in Minutes (MEAN) aFter 90 Minutes of Passive Hyperventilation (INDLCTION WITH $20 \mathrm{mg} / \mathrm{kg}$ ThIOPENTONE)

\begin{tabular}{|c|c|c|c|c|}
\hline Maintenance Anaesthetics & Approx. & $\begin{array}{l}\text { S.R. } \\
\text { (min) }\end{array}$ & $\begin{array}{l}\text { S.A. } \\
\text { (min) }\end{array}$ & $\begin{array}{l}\text { Total recovery } \\
\text { time (min) }\end{array}$ \\
\hline $\begin{array}{l}\text { Methoxyflurane } 0.5 \%+50 \% \mathrm{~N}_{2} \mathrm{O} \\
\text { Chloroform } 1.0 \%+50 \% \mathrm{~N}_{2} \mathrm{O} \\
\text { Trichlorethylene } 1.5 \%+50 \% \mathrm{~N}_{2} \mathrm{O} \\
\text { Halothane } 1.0 \%+50 \% \mathrm{~N}_{2} \mathrm{O} \\
\text { Halothane-Ether azeotrope } 3.5 \%+50 \% \mathrm{~N}_{2} \mathrm{O} \\
\text { Isoflurane } 3.5 \%+50 \% \mathrm{~N} \mathrm{~N}_{2} \mathrm{O} \\
\text { Enflurane } 3.5 \%+50 \% \mathrm{~N}_{2} \mathrm{O} \\
\text { Diethyl Ether } 10.0 \%+50 \% \mathrm{~N}_{2} \mathrm{O} \\
\text { Fluroxene } 5.0 \%+.50 \% \mathrm{~N}_{2} \mathrm{O} \\
\text { Innovar } 1 \mathrm{ml} / 8 \mathrm{~kg} \\
\text { Thiopentone } 30 \mathrm{mg} / \mathrm{kg}\end{array}$ & $\begin{array}{l}2 \\
3 \\
4 \\
2 \\
4 \\
3 \\
2 \\
3 \\
1 \\
-\end{array}$ & $\begin{array}{r}23 \\
18 \\
21 \\
22 \\
35 \\
35 \\
24 \\
8 \\
19 \\
20 \\
27\end{array}$ & $\begin{array}{l}30 \\
35 \\
71 \\
25 \\
59 \\
66 \\
39 \\
68 \\
42 \\
22 \\
34\end{array}$ & $\begin{array}{r}53 \\
73 \\
92 \\
47 \\
94 \\
101 \\
63 \\
76 \\
61 \\
42 \\
61\end{array}$ \\
\hline
\end{tabular}

per cent with all the anaesthetics. Blood sugar always rose, the largest changes occurring with diethyl ether, fluroxene and trichlorethylene. Changes in serum inorganic phosphorus were variable and not significant. Diethyl ether was the only annesthetic that caused an appreciable rise in the lactate/pyruvate ratio and production of excess lactate. The alterations observed with enflurane and isoflurane were small and of the same order as in our previous comparative studies when the pulmomary ventilation provided isocarbic conditions. ${ }^{10,12}$

\section{Biogenic Amines and Plasma Insulin (Table VI)}

There were no significant changes in biogenic amines and plasma insulin, although there was a trend to an elevated plasma histamine with halothane. Serotonin values varied considerably but were in general lower than previously observed with isocirbic pulmonary ventilation or with hypoxia. ${ }^{12,13}$ The changes in the catecholamine estimations were insignificant except with halothane and diethyl ether but, as noted in other studies, ${ }^{10}$ they vere too small to be clinically important.

\section{Recovery from Anaesthesia (Table VII)}

Resumption of spontaneous breathing after anaesthesia with passive hyperventilation was discontinued usually took 20 to 35 minutes except with diethyl ether, which usually took less than 10 minutes. Full recovery to steady ambulation usually took an hour or more. Steady ambulation returned late after isoflurane, probably because of the potent muscle relaxant effect of this anaesthetic. Recovery was especially slow after trichlorethylene, halothane-ether azeotrope and isoflurane and was attributed mainly to the deep level of inhalation anaesthesia that was used. Shivering during recovery was seen after six experiments; three after halothane-ether azeotrope, one after fluroxene and two after diethyl ether. Although the laboratory data did not show exceptional differences, the animals were "groggy" for a considerable time after chloroform and diethyl ether and the dogs usually did not take food until the day after these anaesthetics. Several of these animals were given a dextrose-in-water infusion intravenously during the postoperative period to ensure full recovery. Once recovered after 
halothane, isoflurane and enflurane, the dogs returned essentially to normal activity. They ate solid food and drank water. After the remaining anaesthetics, the dogs were normal within a few hours. The time to awakening was not specifically recorded or compared among these or with our previous tests because different "MAC" concentrations were used. The main factor in our choice of the concentration administered was to ensure survival of the dog after each experiment so that all agents could be compared. It was therefore expected that time of awakening would vary, as did the recovery of steady ambulation (Table VII). The 22 dogs survived all of the tests and were in good clinical condition throughout the series.

\section{Discussion}

Passive hyperventilation is so widely used for treatment of a variety of clinical syndromes that are associated with severe respiratory depression due to primary disease of the lungs or secondary to cardiac, renal, brain and neurological disorders, that those who have feared its possible deleterious effect on cerebral blood flow or myocardial contractility hardly acknowledge this problem now, as long as an excess oxygen tension is not maintained in the lungs and arterial blood and the ventilator cycling is adjusted so as to minimize obstruction of venous return to the heart. ${ }^{14}$

Ever since Geddes and Gray popularized the application of passive hyperventilation in anaesthesia to reduce or eliminate the use of anaesthetic vapours and to permit complete reliance on nitrous oxide and profound skeletal muscle relaxation by muscle relaxant drugs, their conclusion that it is both harmless and conducive to good operating conditions has been challenged repeatedly. ${ }^{15-43}$ They believe that the hyperventilation helps to ensure complete analgesia and unconsciousness (hypnosis) during even the most stimulating surgical procedures, and recovery is rapid.24,25 Contradictory evidence remains substantially questionable clinically despite laboratory studies that might point to evanescent reduction in cerebral perfusion, ${ }^{21}$ hypotension, delay in recovery from anaesthesia, ${ }^{2: 3}$ pathognomonic alterations in the flicker-fusion test ${ }^{11}$ and increased fixed acids in the blood..$^{17}$

Even if a surgical depth of anaesthesia is added to nitrous oxide with an inhalation or parenteral agent, but without muscle relaxants, the changes we observed in the electrocardiogram and in cardiovascular dynamics and metabolic functions were not substantially different from those seen with isocarbic-controlled pulmonary ventilation, ${ }^{10,12}$ and agree with earlier reports. ${ }^{26-29}$ Myocardial oxygen consumption: $: 10-3: 2$ is probably decreased with several inhalation anaesthetics currently in wide use (halothane, enflurane, methoxyflurane and with Innovar) (Table VIII). No clinical signs of persistent cerebral effects from passive hyperventilation and hypocarbia were observed, such as slow recovery, tetany, ataxia, in spite of administering deep surgical anaesthesia, even with enflurane and isoflurane.

\section{Summary AND ConClusions}

Studies were carried out on 22 large, male, mongrel dogs at two-week intervals, in a crossover design, to determine the metabolic, blood-gas and cardiovascular 
TABLE VIII

Comparative Effect of Passive Hyperventilation ON MYOCARDIAL OXYGEN REOUIREMENT DURING: Surgical Anaesthesia as Reflected by the Heart Rate $\times$ Sistolic Blood Presscire (BEGINNING TO END OF TEST)

\begin{tabular}{|c|c|c|}
\hline \multicolumn{2}{|c|}{$\begin{array}{c}\text { Annesthetics administered with } \\
50 \% N_{2} \mathrm{O} \text { after induction with } \\
20 \mathrm{mg} / \mathrm{kg} \text { thiopentone }\end{array}$} & \multirow{2}{*}{$\begin{array}{c}\% \text { Change in } \\
\mathrm{O}_{2} \text { consumption } \\
-29\end{array}$} \\
\hline Methoxyflurane & $0.5 \%$ & \\
\hline Chloroform & $1.0 \%$ & +3 \\
\hline Trichlorethylene & $1.5 \%$ & +3 \\
\hline Halothane & $1.0 \%$ & -4 \\
\hline HE Azeotrope & $3.5 \%$ & -41 \\
\hline Isoflurane & $3.5 \%$ & -61 \\
\hline Enfurane & $3.5 \%$ & -52 \\
\hline Diethyl ether & $10.0 \%$ & +7 \\
\hline Fluroxene & $5.0 \%$ & +10 \\
\hline Innovar & $1 \mathrm{ml} / \mathrm{s} \mathrm{kg}$ & $-4 i 5$ \\
\hline Thiopentone & $30 \mathrm{mg} / \mathrm{kg}$ & +26 \\
\hline
\end{tabular}

effects, and the rate of recovery to steady ambulation from a surgical depth of general anaesthesia administered with passive hyperventilation. To prepare the animal, induction of anaesthesia was accomplished with $20 \mathrm{mg} / \mathrm{kg}$ body weight of 2 per cent thiopentone, tracheal intubation and inhalation of 50 per cent nitrous oxide and oxygen. After attachment of recording equipment and drawing of control blood samples, a respirator was attached to the anaesthetic circuit to provide passive hyperventilation by providing pulmonary ventilation of $15 \mathrm{ml} / \mathrm{kg}$ body weight at the rate of approximately 25 cycles per minute for 90 minutes, adding an aniesthetic concentration of methoxyflurane, chloroform, trichlorethylene, halothane, halothane-ether, azeotrope, isoflurane, cnflurane, diethyl ether, or fluorexene from an out-of-circuit calibrated vapourizer. Thiopentone and Innovar were also tested and were given by an intravenous drip infusion. Nitrous oxide 50 per cent was given with 50 per cent oxygen with all the maintenance agents. No muscle relaxiants were used and no stimulants were administered at the end of the test period.

The data support the advantages of passive hyperventilation which have been reported. Full oxygenation is maintained; mild respiratory alkalosis is generally safe with particular respect to the incidence of ventricular arrhythmias and effect on myocardiac contractility (as judged by the lack of appreciable hypotension); metabolic acidosis does not occur except with diethyl ether; excess lactate accumulation is no greater than with isocarbic pulmonary ventilation and is negligible except with diethyl ether. Myocardial oxygen consumption is probably not increased with halogenated aniesthetics except with fluroxene, chloroform and trichlorethylene. The hypotension that occurred with some of the anaesthetics $(\sim 30$ per cent $)$ is an inherent effect of a surgical depth of general anaesthesia on the peripheral vascular resistance and occurs also with the non-depolarizing skeletal muscle relaxants. Full recovery after anaesthesia with passive hyperventilation is not delayed significantly, since deep general anaesthesia was not greatly prolonged. Recovery of spontaneous respiration was rapid after diethyl ether 
( $<10$ minutes) but took approximately 30 minutes (means of 18 to 35 minutes) with the other agents. Steady ambulation usually took approximately 45 minutes longer (means of 25 to 71 minutes) due to muscle weakness after isoflurane, enflurane and methoxyflurane and a prolonged hypnotic effect of the other agents. Neuromuscular disturbances did not occur with enflurane or isoflurane in any of the tests in spite of fairly deep anaesthesia and induction of hypocarbia.

On the basis of these animal experiments, there appear to be no obvious disadvantages to the employment of moderate passive hyperventilation for surgical anaesthesia with inhalational or parenteral anaesthetics.

\section{RÉSUMÉs Et CONCLUSIONS}

Les expériences ont été effectuées sur 22 gros chiens mâles, à deux semaines d'intervalle, selon un mode répétitif et croisé (crossover). Elles visaient à déterminer les effets métaboliques et les répercussions sur les gaz sanguins et le système cardiovasculaire de l'anesthésie générale chirurgicale combinée à l'hyperventilition passive. La rapidité de l'éveil et la récupération d'une ambulation stable ont été également étudiées. L'induction de l'anesthésie et la préparation de l'animal ont été effectuées au moyen de thiopental $20 \mathrm{mg} / \mathrm{kg}$, intubation endotrachéale, inhalation de 50 pour cent de protoxyde d'azote et d'oxygène. Après mise en place des systèmes d'enregistrement et de prélèvement des échantillons sanguins de contrôle, un respirateur était branché dans le circuit d'anesthésie et réglé de façon à assurer durant 90 minutes une hyperventilation passive (volume courant de $15 \mathrm{ml} / \mathrm{kg}$ et une fréquence de $25 /$ minute). Une concentration anesthésique de méthoxyflurane, chloroforme, trichloréthylène, halothane, halothane azéotropeéther, isoflurane, diéthyl éther, ou fluroxène, était administrée à l'aicle d'un vaporisateur calibré, situé hors du circuit. Le thiopental ou l'imnovar ont été également testés, en perfusion continue. Tous ces agents anesthésiques ont été donnés avec un mélange de 50 pour cent oxygène-protoxyde d'azote. Les chiens n'ont reçu ni relaxints musculaires, ni stimulants à la fin des expériences.

Les données confirment les avantages déjà reportés de l'hyperventilation passive. Une pleine oxygénation est maintenue; l'alcalose respiratoire modérée représente une technique généralement sîre, en particulier en regard de l'incidence des arythmies ventriculaires et de l'effet sur la contractilité myocardique reflétés par l'absence d'hypotension appréciable; il ne se produit pas d'acidose métabolique, ni d'accumulation cxcessive de lactates, en comparaison avec la ventilation isocarbique (excepté avec l'éther diéthylique). La consommation d'oxygène myocardique n’augmente probablement pas avec les agents halogénés (le fluroxène, le chlorotorme, et le trichloréthylène exceptés).

L'hypotension notée avec certains des agents testés (environ 30 pour cent est due à l'action de l'anesthésie générale chirurgicale sur les résistances périphériques; elle se voit aussi avec les relaxants musculaires non dépolarisants. L'éveil complet après l’anesthésie avec hyperventilation passive n'est pas retardé de façon significative, et l'anesthésie générale profonde n'est pas nettement prolongée. La reprise de la ventilation spontanée est rapicle avec le diéthyl éther (moins de 10 minutes) mais demande environ 30 minutes avec les autres agents (durées de 18 à 35 
minutes). Le retour à une ambulation stable demande environ 45 minutes de plus (valeurs de 21 à 71 minutes) en raison de faiblesse musculaire après isoflurane, enflurane et méthoxyflurane et à cause de l'effet hypnotique prolongé avec les autres agents. On n'a pas observé de troubles neuromusculaires avec l'enflurane et l'isoflurane malgré l'anesthésie profonde et l'hypocarbie induite.

Les expériences animales n'ont donc pas révélé de désavantage évident à l'usage de l'hyperventilation passive modérée dans l'anesthésie chirurgicale avec des agents d'inhalation ou intraveineux.

\section{ACKNOWLEDGMENTS}

This project was supported by grants-in-aid from Ayerst Laboratories, AIRCO Inc., U.S.P.H.S. Grant 05402-04,5 and by The Division of Research Facilities and Resources of N.I.H. (Grant FR00353).

The authors appreciate the excellent technical assistance of the following members of this project: Christina Bisset, R.N.; Robert Gelder, B.S., R.T.; George D. Mann, R.T.; Sandra Menjik, B.S., R.T., and John W. White, B.A.

\section{REFERENCES}

1. Virtue, R.W., Lund, L.O., Phelps, M., Vogel, J.H.K., Beckwitt, H., \& Henon, M. Difluoromethyl 1,1,2-trifluoro-2-chloroethyl ether as an anaesthetic agent. Results with dogs and a preliminary note on observations with man. Canad. Anaesth. Soc, J. 13: $233(1966)$.

2. Dohkin, A.B., Nishoka, K., Gengaje, D.B., Kim, D.S., Evers, W., \& Israel, J.S. Ethrane (compound 347) anesthesia: a clinical and laboratory review of 700 cases. Anesth, \& Anilg. 48: 477 (1969).

3. Nismioka, K. \& Dobks; A.B. Ethrane: effect of hyperventilation. Jap. J. Anaesth. 18 : $679(1969)$.

4. Joas, T.A., STevexs, W.C., \& Eger, E.I., II. Electroencephalographic seizure activity in dogs during inaesthesia: Studies with Ethrane, fluroxene, halothane, chloroform, divinyl ether, diethyl ether, methoxyflurane, cyclopropane, and forane. Brit. J. Anaesth. 43: 739 (1971).

5. Clakk, D.L. \& Rosser, B.S. Neurophysiologic effects of general anesthetics. 1. The electroencephalogram and sensory responses in man. Anesthesiology 38: 564 (1973).

6. Neville, J.F., jR. \& Gelder, R.L. Modified enzymatic methods for the determination of L- $(+)$-lactic acid and pyruvic acid in blood. Am. J. Clin. Path. 55: 152 (1971).

7. NoAн, J.W. \& Brasd, A. Simplified micromethod for measuring histanine in human plasma. J. Lab. Clin. Med. 62 : 506 (1963).

8. Axton, A.H. \& SAYlie, D.F. A study of the factors affecting the aluminum oxide trihydroxyindole procedure for analysis of catecholamines. J. Phamacol. Exp. Therap. 138: $360(1962)$.

9. Mongax, C.R. \& Lazanow, A. Immunoassay of insulin: two antibody system. Diabetes 12: $115(1963)$

10. Dobkix, A.B., Byles, P.H., Arandia, H.Y., Ghanooni, S., Nishoka, K., \& Levy, A.A. Comparative metabolic responses to halogenated anaesthetics. Acta Aniesth. Scandinav. 16: 69 ( 1972).

11. Byles, P.H., Donkin, A.B., Fercuson, J.H., \& LevY, A.A. Forane (compound 469): crossover comparison with enflurane (Ethrane), halothane and methoxyflurane in dogs. Canad. Anaesth. Soc. J. 18: 376 (1971).

12. Dовкім, A.B., BxLes, P.H., \& Nevilie, J.F., Jr. Neuroendocrine and metabolic effects of general anaesthesia during spontaneous breathing, controlled breathing, mild hypoxia and mild hypercarbia. Canad. Anaesth. Soc. T. 13130 (1966).

13. Doвkin, A.B., Byles, P.H., \& Levy, A.A. Enflurane (Ethrane) and Isoflurane (Forane): a comparison with nine general anaesthetics during stress of hypoxia (spontaneous breathing ). Canad. Anaesth. Soc. J, 20:782 (1973). 
14. Pontoppidax, H., Hedley-Whyte, I., Bexdixen, H.H., Laver, M.B., \& Radforid, E.P. Ventilation and oxygen requirements during prolonged artificial ventilation in patients with respiratory failure. New Engl. J. Med 273: 401 (1965)

15. Geddes, I.C. \& GraY, T. Hyperventilation for the maintenance of anaesthesia. Lancet II $4(1959)$.

16. Cuutrox-Bноск, J. The cerebral effects of hyperventilation. Brit. I. Anaesth. 29: 111 (1957).

17. Papadopoulos, C.N. \& Keats, A.S. The metabolic acidosis of hyperventilation produced by controlled respiration. Anesthesiology 20: 156 (1959).

18. Sucioka, K. \& Davis, D.A. Hyperventilation with oxygen: possible cause of cerelural hypoxia. Anesthesiology 21:135 (1960).

19. Allex, G.D. \& Monms, L.E. Central nervous system effects of hyperventilation during anaesthesia. Brit. J. Anaesth. 34: 296 (1962).

20. Pience, E.C., Lashertson; C.J., Deutsch, S., Chase, P.E., Linde, H.W., Dripps, R.D., \& Puce, H.L. Cerebral circulation and metabolism during thiopental anaesthesia and hyperventilation in man. J. Clin. Invest. 41: 1664 (1962).

21. MCDowelL, D.C. \& Harper, A.M. CBF and CSF pH in monkey during prolonged hypocapnia Scand. J. Lab. Clin. Invest., Suppl. 102 (1968).

22. Chaiduerlats, J.H. \& Liss, M.T. Olsservations of blood lactate and pyrusate levels and excess lactate production during and after anaesthesia with and without hyperventilation. Brit. J. Aninesth. 40: 315 (1968).

23. Wollaras, S.B. \& OnkIs, L.R. Postoperative human reaction time and hypocarbia during innaesthesia. Brit. J. Anacsth. 40: 920 (1968).

24. Romsson, J.S. \& Gray, T.C. Olservations on the cerebral effects of passive hyperventilition. Brit. J. Analesth. 33: 62 (1961).

25. Utrisc, J.E. \& GraY, T.C. The initiation of respiration after anacsthesia accompanied by passive pulmonary hyperventilation. Brit. J. Anaesth. 34: 785 (1962).

26. Millei, F.A., Brows, E.B., Buckley, T.J., Vax Bergex, F.H., \& Vahco, R.L. Respiritory acidosis: its relationship to cardiac function and other physiologic mechanisms. Surgerv. 32: $171(1952)$.

27. Bnowx, E. B. Jr. Physiological effects of hyperventilation. Physiol. Rer. 33: 445 (1953).

28. WEAD, W.B. \& LITTLE, R.C. Effect of hypocapnia and respiritory alkalosis on caldiac contrictility. Proc. Soc. Exp. Biol. \& Med. 126: 606 (1967).

29. SYKEs, M.K. \& Cooke, P.M. The effect of hyperventilation on "excess lactate" production during anaesthesia. Brit. J. Anaesth. 37: 372 (1965).

30. Braunwald, E. Control of myocardial oxygen consumption. Am. J. Cardiol. 27: 416 (1971).

31. Rноре, E. Uber den einfluss der mechanischen bedingungen, auf die tatigkeit und den sauerstoff - verbrauch des warmbluterherzens. Arch. exp. Path. Pharmak. 64: 406 (1912).

32. Nelsox, R.R., Gobel, F.L., Jorgevisex, C.R., WaNe, K., WANg, Y., \& TAYLOR, H.L. Hemodynamic predictors of myocardial oxygen consumption during static and dynamic exercise. Circulation 50: 1179 (1974). 